\title{
Kwestia upamiętnień władców Wielkiego Księstwa Litewskiego w polityce historycznej współczesnej Białorusi
}

Słowa kluczowe: polityka historyczna Białorusi, Wielkie Księstwo Litewskie, pomniki, kultura pamięci

Keywords: historically-oriented policy of Belarus, the Grand Duchy of Lithuania, monuments, culture of remembrance

Abstract: Lately, a distinct change took place in the Belarus authorities' attitude towards the legacy of the Grand Duchy of Lithuania. One of the aspects of the changes occurring in the Belarus historically-oriented policy is opening up to commemorating figures from those times.

W ciągu ostatnich lat w polityce historycznej Białorusi można zauważyć zachodzące interesujące zmiany. Coraz częściej pojawiają się w niej elementy dotyczące aspektów poświęconych spuściźnie Wielkiego Księstwa Litewskiego, a w tym najważniejszych postaci z tego okresu. Jej bardzo ważnym komponentem jest kwestia związana z pomnikami ku czci bohaterów narodowych. W kwestii budowy nowych pomników na Białorusi widać pewną zmianę w postrzeganiu tego aspektu przez władze państwowe. Jeszcze do niedawna upamiętnianie postaci historycznych symbolizujących władców Wielkiego Księstwa Litewskiego wydawało się jeśli nie niemożliwe, to mało prawdopodobne. Nadal jednak, mimo pewnych zmian w tym względzie, wzbudza to emocje i jest przedmiotem sporów oraz dyskusji. W trakcie ostatniej dekady dotyczyly one tak władców WKL (takich jak Mendog, Olgierd czy Witold), 
jak i innych przedstawicieli elit wywodzących się z Wielkiego Księstwa Litewskiego. Wśród nich wymienić można m. in. Dawida Grodzieńskiego (Dowmontowicza), Lwa Sapiehę, Tadeusza Kościuszkę czy też Adama Mickiewicza ${ }^{1}$.

W ostatnich latach w Europie wyraźnie wzrosło zainteresowanie badawcze dotyczące zagadnień związanych z szeroko rozumianą tematyką pamięci historycznej, by wspomnieć choćby takich badaczy jak Pierre Nora czy Jan Assman, których nowatorskie koncepcje dotyczące „miejsc pamięci” i pamięci kulturowej ${ }^{3}$ zainspirowały cały szereg prac z różnych dziedzin humanistyki. Istotną dla naszych dalszych rozważań kulturę pamięci zdefiniował naukowo niemiecki badacz Christoph Cornelißen, uznając ją za pojęcie nadrzędne dla wszelkich możliwych form świadomej pamięci wydarzeń historycznych, osobistości i procesów, niezależnie od tego, czy są one natury estetycznej, politycznej czy kognitywnej. Obejmuje ono, oprócz form ahistorycznej czy wręcz antyhistorycznej pamięci zbiorowej, wszystkie inne sposoby reprezentacji historii, w tym dyskurs naukowo-historyczny oraz „prywatne” wspomnienia, o ile zostawiły one ślady w przestrzeni publicznej. Jako podmioty tej kultury występują jednostki, grupy społeczne lub wręcz narody i państwa ${ }^{4}$. Pojęcie to używane bywa również w węższym znaczeniu, dotyczy wówczas ekspansji praktyk upamiętniania spuścizny II wojny światowej, a zwłaszcza Holocaustu, do jakiej dochodzi od końca XX w. W tym znaczeniu stosuje je przede wszystkim Aleida Assmann ${ }^{5}$. Definicje Cornelißena i Assmann łączą się ze sobą, bo konieczność przepracowania przeszłości i traum związanych z historią XX w. przyczyniła się do szerszego zainteresowania tematyką pamięci i stworzenia pojęcia opisującego sposoby obchodzenia się z przeszłością. Kultura pamięci powiązana jest blisko z polityką

1 Trzeba zaznaczyć, że podane tu postacie związane są nie tylko z tradycją białoruską, ale i z polską i litewską, należą więc do wspólnej przestrzeni pamięci tych trzech narodów. Szerzej na temat badania kontekstów historycznych współczesnej pamięci zbiorowej Polaków zob.: M. Micińska, Między królem duchem a mieszczaninem. Obraz bohatera narodowego w piśmiennictwie polskim przełomu XIX i XX w. (1890-1914), Wrocław 1995; por. też R. Traba, Przeszłość w teraźniejszości, Poznań 2009.

2 P. Nora, Między pamięcia i historią. Lieux de memoire, przeł. M. Mościcki, Tytut roboczy: archiwum, red. M. Ziółkowska, A. Leśniak, 2009/2, s. 4; na temat koncepcji P. Nory zob. też A. Szpociński, Miejsca pamięci (lieux de mémoire), Teksty Drugie, 4/2008, s. 11-20.

3 J. Assmann, Pamięć kulturowa. Pismo, zapamiętywanie i polityczna tożsamość w cywilizacjach starożytnych, tłum. A. Kryczyńska-Pham, Warszawa 2008.

4 Ch. Cornelißen, Czym jest kultura pamięci. Pojęcie - metody - perspektywy, tłum. E. Bagłajewska-Miglus, [w:] Konteksty pamięci. Antologia, red. K. Kończal, Warszawa 2014, s. 255.

5 Aleida Assmann: Między pamięcią a historią. Antologia, Warszawa 2013. 
historyczną. Ale o ile ta druga związana jest ściśle z działaniem państwa i instytucjonalizacją pamięci i do jej przejawów należy m.in. stawianie pomników, tworzenie muzeów i organizowanie oficjalnych uroczystości ${ }^{6}$, to ta pierwsza jest pojęciem szerszym i można ją ująć jako strukturalne, społeczne i kulturowe ramy, w których uprawiana jest polityka historyczna ${ }^{7}$. Odnosi się to także do przypadku białoruskiej kultury pamięci, w tym jej stosunku do dziedzictwa Wielkiego Księstwa Litewskiego, przeżywającego w ostatnich dziesięcioleciach znamienną ewolucję.

Kryzys i upadek ZSRR oraz powstanie niepodległego państwa białoruskiego sprawiło, że szeroko rozumiane badania nad „polityką historyczną” stają się coraz bardziej popularne wśród współczesnych białoruskich historyków, takich jak m.in.: A. Wielikij ${ }^{8}$, G. Łazko $^{9}$, H. Sahanowicz ${ }^{10}$, A. Smolanczuk ${ }^{11}$, Z. Szybieka ${ }^{12}$ oraz W. Snapkowski ${ }^{13}$. W białoruskiej historiografii wskazuje się na trzy etapy jej kształ-

6 Por. np. J. Rydel, Polityka historyczna w Republice Federalnej Niemiec. Zaszłości, idee, praktyka, Kraków 2011; E. Ponczek, A. Sapkowski, red., Mity historyczno-polityczne, wyobrażenia zbiorowe, polityka historyczna, t. 1-3, Toruń 2010-2013; S. M. Nowinowski, J. Pomorski, R. Stobiecki, red., Postpamięć i polityka historyczna. Doświadczenia Polski i jej sąsiadów, Łódź 2008; B. Korzeniewski, red., Narodowe i europejskie aspekty polityki historycznej, Poznań 2008; patrz też specjalny numer czasopisma Pro et Contra, 2009, nr 3-4, poświęcony tej kwestii, a szczególnie teksty A. Millera, H. Kasjanowa I R. Traby (Мимер А. И. Россия: Власть и история, s. 6-23, Георгий Касьянов Голодомор и строительство нации, s. 24-42, Роберт Траба. Польские споры об истории в ХХI веке, s. 43-64, http://carnegieendowment.org/files/ProEtContra_3.2009_all_screen.pdf.

7 Szerzej na temat specyfiki kultury pamięci w Europie Wschodniej por. m.in. S. Troebst, Postkomunistyczne kultury pamięci w Europie Wschodniej: stan, kategoryzacja, periodyzacja. Wrocław 2005.

8 А. Вямікі, Гістарычная палітыка ў Беларусі: 1921-1939 г2. Польскі накірунак, [w: ] Спрычныл пытанні. 3 гісторыі польска-беларускіх узаемаадносін у 1918-1945 г2. Генезіс, кантэкст, вынікі: Зборнік навук. прац II і IV міжнар. навук.-тэарэтыч. канф., Мінск 2013, c. $242-249$.

9 Р Мазько, Парадоксы сучаснай беларускай гістарычнай палітыкі ў адлюстраванні падручнікаў па гісторыі для сярэдняй школь, [w:] Tатże, с. 233-241.

10 Г. Саганович, Историческал политика в постсоветской Беларуси, [w:] Русский вопрос 2009, № 2, http://www.russkiivopros.com/index.php?pag=one\&id=278\&kat=5\&csl=42 .

11 А. Смахянчук, „Савецзкасиъ” беларускай постсавецкай гістарыяграфіi, [w:] Спрэчныя пьтанні, с. 224-229.

12 3. Шыбека, Гісторыя як сродак патрылтычнага выхавання ў Беларусі, [w:] Вяртанне у Еўропу: мінулае і будучыня Беларусі, Uczelnia Łazarskiego 2011, с. 178-179.

13 В. Снапковский, Историческал политика в Беларуси в период перестройки и парламентской республки (1985-1994 г2.), [w:] Труды факультета международных отношений: науч. сборник., Вып. 5., БГУ 2014, с. 62-69. 
towania. Pierwszy rozpoczął się pod koniec lat osiemdziesiątych XX w. i trwał do momentu zorganizowania ogólnokrajowego referendum w maju 1995 r. Charakteryzował się budowaniem białoruskiej tożsamości w oparciu o rozwój języka białoruskiego i narodowo zorientowanej koncepcji badania historii Białorusi ${ }^{14}$. Kolejny etap był ściśle związany z działaniami wybranego w 1994 r. na prezydenta Aleksandra Łukaszenki, który umocniwszy się u władzy zapoczątkował politykę dotyczącą budowy wspólnego Państwa Związkowego Białorusi i Rosji. W związku z tym postanowiono zrezygnować z wcześniejszej pronarodowej (probiałoruskiej) polityki historycznej na rzecz zwiększenia roli języka rosyjskiego ${ }^{15}$ i ukazywania związków historycznych Białorusi z Rosją i kulturą rosyjską. W tym okresie na Białorusi widoczna była silna nostalgia za ZSRR i postępowała resowietyzacja kultury pamię$\mathrm{ci}^{16}$. Wymieniony wyżej okres wyraźnej resowietyzacji kultury pamięci państwa białoruskiego zakończył się w 2003 r., kiedy w Mińsku zdecydowano o budowaniu ideologii państwowej w oparciu o hasło „silnej, dostatniej i niezależnej Białorusi”17. Wiązało się to $\mathrm{z}$ faktycznym niepowodzeniem realizacji projektu państwa związkowego z Federacją Rosyjską, które to wedle nadziei Łukaszenki miało mu zapewnić kierowanie tym politycznym tworem. Plany te przekreśliła zmiana na stanowisku prezydenta Rosji na przełomie 1999/2000 r., kiedy to schorowany Borys Jelcyn zastąpiony został przez młodego i dynamicznego następcę Władymira Putina. Ten ostatni zdołał szybko umocnić swoją pozycję, w konsekwencji na Białorusi od 2003 r., według Włodzimierza Snapkowskiego, następuje „rehabilitacja niektórych narodowych koncepcji historycznych odnoszących się głównie do historii starobiałoruskich księstw i Wielkiego Księstwa Litewskiego, a także XIX w., ostrożne odejście od rosyjsko-radzieckich kanonów interpretacji niektórych tematów historycznych (za wyjątkiem twardej pozycji dotyczącej tematyki Wielkiej Wojny Ojczyźnianej) i zwiększenie treści narodowych w dyskursie historycznym"18. Tworzenie pomników władców związanych z Wielkim Księstwem Litewskim oraz obecność tematyki po-

14 В. Шадурский, Историческая политика в Республке Беларусь: этапь развития и версии интерпретации прошлого, Татże, с. 10.

15 Tamże.

16 А. Браточкин, Культура памлти в Беларуси (1988-2016): от раскола к консервативному консенсусу?, http://gefter.ru/archive/20174.

17 В. Снапковский, Историческал политика в Республике Беларусь в период президенства A. Аукашенко, Wschodnioznawstwo nr 1, Instytut Studiów Międzynarodowych Uniwersytetu Wrocławskiego 2015, s. 162.

18 Tamże, s. 178. 
święconej temu okresowi wpisują się we współczesną politykę historyczną białoruskich władz. Należy jednak zaznaczyć, że prezydent Łukaszenko nie traktuje WKL jako państwa białoruskiego ${ }^{19}$. Ten kraj utożsamia z Litwą funkcjonującą w symbiozie z podległymi jej ziemiami ruskimi ${ }^{20}$.

Jeden z największych sporów dotyczący upamiętnień władców WKL związany był z ideą ustanowienia pomnika wielkiego księcia litewskiego Olgierda w centrum Witebska. Sam pomysł zrodził się wśród przedstawicieli miejskiej administracji w 2010 r. Miało to być drugie na świecie przedstawienie wizerunku tego władcy ${ }^{21}$, a także jeden z pierwszych pomników konnych na Białorusi ${ }^{22}$. Już od początku pomysł ten wzbudził wiele emocji i skrajnych opinii. W gronie przeciwników znalazła się przede wszystkim część społeczności reprezentującej mniejszość rosyjską, a krąg zwolenników oparł się o białoruską młodzież oraz niektórych przedstawicieli nauki. Według badań socjologów przeprowadzonych wśród mieszkańców Witebska niemal połowa z nich, bo aż 49 proc. popierała idee ustanowienia pomnika, a jedynie 12 proc. było temu przeciwnych ${ }^{23}$.

Dla próby zrozumienia argumentów dwóch stron należy najpierw przybliżyć postać księcia Olgierda Giedyminowicza. Urodził się on około 1303-1305 r. ${ }^{24}$ Był synem wielkiego księcia litewskiego Giedymina oraz księżniczki połockiej Jewny, a także bratem Narymunta (ok. 1300-1348), Witolda (ok. 1303-1336), Koriata

19 В. Шадурский, Историческая политика в Республие Беларусь, s. 14.

20 Tamże.

21 Pierwsze na świecie przedstawienie wizerunku księcia Olgierda ukazało się na pomniku Tysiąclecia Rosji w Nowogrodzie Wielkim w 1862 r. (obok wizerunku Giedymina i Witolda).

22 Wedle prasy białoruskiej jest to czwarty z kolei pomnik konny na Białorusi. Dwa takie pomniki poświęcone pamięci poległych czerwonoarmistów znajdują się na Mohylewszczyźnie; najstarszy, z 1981 r., znajduje się na zbiorowej mogile pod wsią Gornia w rejonie chocimskim na granicy z Rosją i przedstawia kawalerzystę na koniu (upamiętnia żołnierzy 112 pułku kawaleryjskiego 13 armii poległych w sierpniu 1941 r., drugi z 1999 r. poświęcony jest żołnierzom Armii Czerwonej poległym przy wyzwalaniu Bobrujska w 1944 r. i przedstawia Świętego Grzegorza w mundurze czerwonoarmisty, który przebija lancą smoka-węża w kształcie faszystowskiej swastyki, trzeci odsłonięty został w 2007 r. w Połocku i przedstawia księcia połockiego Wsiesława Carodzieja, por. Т. Матвеева, Князь Ольгерд вернулся в Витебск подливень с градом. Как устанавливали монумент в честь исторического деятеля, http://news.tut.by/society/404420. html (11 VI 2016) http://belchas.by/news/khotimskii-raion-dalnii-vostok-belarusi.html (12 VI 2016).

23 Какие памятники нужны Беларуси? Мекиия-опрос проила в Минске, http:/ /ont.by/news/ our_news $/ 00120874$ ?page $=6559$ (10 VI 2016).

24 J. Tęgowski, Pierwsze pokolenie Giedyminowiczów, Poznań-Wrocław 1999, s. 47. 
Michała (ok. 1306-ok. 1365) i Jawnuty (ok. 1306-ok. 1366). W 1318 r. ożenił się z księżniczką Marią ${ }^{25}$ - córką księcia witebskiego Jarosława Wasilewicza. Po jego śmierci w 1320 r., kiedy męska linia książąt wygasła, ziemia witebska przeszła w spadku na córkę, a sam Olgierd został księciem witebskim. W ten sposób dzięki małżeństwu obszar ten stał się później częścią Wielkiego Księstwa Litewskiego, co jest szczególnie podkreślane w białoruskich podręcznikach ${ }^{26}$. Kwestia dotycząca pierwszej żony księcia Olgierda została podjęta przez Jana Tęgowskiego w „Pierwszym pokoleniu Giedyminowiczów”. Ustalił on, iż w „Rodowodzie kniaziów witebskich" (uznaje go za mało wiarygodny) występuje żona Olgierda o imieniu Maria. Jednak w „Kronice Bychowca” nosi ona imię Anna - podobnie jak w „Latopisie ewreinowskim" 27 . Autor skłania się ku temu, iż w tym ostatnim przypadku mowa jest o drugiej żonie Olgierda - Juliannie Twerskiej ${ }^{28}$. Według Jana Tęgowskiego zastosowanie dwóch imion nie musi oznaczać tego, że były to dwie różne osoby - jedno z tych imion można uznać za imię zakonne ${ }^{29}$. Dochodzi on również do wniosku, iż pierwsza żona Olgierda musiała pochodzić z rodziny prawosławnej, ze względu na jej chrześcijańskie imię. Jednak, według niego, nie mamy pewności, czy Maria Anna była córką księcia witebskiego Jarosława Wasilewicza ${ }^{30}$. Wątpliwości co do pierwszej żony Olgierda nie podziela jednak większość polskich historyków, tak tych dawniejszych jak np. Józef Wolff. Według niego była nią właśnie księżniczka witebska Maria $^{31}$. Tego samego zdania był Henryk Wisner, który jednoznacznie określił, iż to Maria była pierwszą żoną księcia ${ }^{32}$.

Książę Olgierd zapisał się w historii Wielkiego Księstwa Litewskiego jako wybitny władca i polityk potrafiący realnie spoglądać w przyszłość i przewidywać skutki swych działań. To dzięki jego współpracy z bratem Kiejstutem udało mu się odsunąć

25 Z. Kiaupa, J. Kiaupiene, A. Kuncevicius, Historia Litwy-Od czasów najdawniejszych do 1795 roku, Warszawa 2007, s. 118.

26 Н. Сташкевич, Г. Голенченко, И. БогАановича, История Беларуси - пособие для подготовки к иентрализованному тестированию, Аверсэв 2011, s. 46.

27 J. Tęgowski, Pierwsze pokolenie, s. 48.

28 Tamże.

29 Tamże, s. 49.

30 Tamże, por. też J. Tęgowski, Kilka słów o matżeństwach wielkiego księcia litewskiego Olgierda Giedyminowica, http://www.nbuv.gov.ua/old_jrn/Soc_Gum/Uks/2011_20/43_Tgowski.pdf (12 VI 2016).

31 J. Wolff, Ród Giedymina, Kraków 1886, s. 26.

32 H. Wisner, Litwa - dzieje państwa i narodu, Warszawa 1999, s. 15. 
od władzy nieudolnego księcia Jawnutę i zapobiec rozbiciu dzielnicowemu. Wielkim Księciem Litewskim Olgierd został w 1345 r. W pierwszych latach jego rządów kraj znajdował się pod dużym zagrożeniem ze strony sąsiednich państw. W latach 1345-1348 toczono walki z Zakonem Krzyżackim, w 1349 r. Polacy zajęli Ruś Halicką wraz z Brześciem i Podlasiem. Złota Orda stroniła od układów z Olgierdem przeciwko Moskwie, a Psków i Nowogród Wielki zaczęły odwracać się od niego ${ }^{33}$. Dużym osiągnięciem władcy było uzyskanie zgody na utworzenie metropolii prawosławnej w Wielkim Księstwie Litewskim w 1354 r. Dzięki temu książę mógł prowadzić dalszą konsolidację i ekspansję na ziemiach ruskich, a także zmniejszyć wpływy Moskwy. Za jego panowania przyłączono do księstwa wiele z tych ziem. Państwo zwiększyło swój obszar dziesięciokrotnie, zajmując część terytoriów należących współcześnie do Białorusi i Ukrainy. Oprócz tego książę podczas swego panowania organizował trzy wyprawy na Moskwę $(1368,1370,1372)^{34}$. Jednak żadna z nich nie zakończyła się sukcesem. Książę Olgierd oceniany jest przez historyków jako silny, nieskrępowany interesami innych członków dynastii władca ${ }^{35}$. Zmarł w 1377 r. pozostawiając po sobie w miarę silne i rozległe terytorialnie państwo.

Idea ustanowienia pomnika księcia spotkała się z pozytywnym odbiorem wśród części białoruskiego społeczeństwa. Pomysł ten był wspierany przez liczną grupę zwolenników. Za pośrednictwem portali społecznościowych próbowali oni dotrzeć do osób mogących wpłynąć korzystnie na działania władz miejskich. W związku z tym zorganizowano akcję polegającą na przekazywaniu petycji do decydentów miasta Witebska, w której odniesiono się do pomysłu. Pisano w niej, iż: „Князь Альгерд зрабіў вялікі ўнёсак у абарону Віцебска і Віцебскай зямлі, іх гістарычнае і культурнае развіццё, а таксама адыграў значную ролю ў гісторыі Беларусі. У сувязі з гэтым хацекася 6 выказаць ўпэуненасць, што помнік гэтаму гістарычнаму Азеячу толькі ўпрыгожыць наш Віцебск, паспрыяе патрыятычнаму выхаванню молаАзі, стане нагодай аля гонару за гораА з боку мясцовых жыхароў і ўсіх грамаАзян Рэспублікі Беларусь" ${ }^{36}$. Zwrócono zatem uwagę głównie na historyczne znaczenie księcia Olgierda dla ziemi witebskiej oraz Białorusi, a także na współczesny wymiar patriotyzmu wśród białoruskiej młodzieży. Wśród zwolenników

33 J. Ochmański, Historia Litwy, Wrocław 1990, s. 54.

34 H. Łowmiański, Studia nad dziejami Wielkiego Księstwa Litewskiego, Poznań 1983, s. 398.

35 Z. Kiaupa, J. Kiaupiene, A. Kuncevicius, Historia Litwy-Od czasów najdawniejszych do 1795 roku, Warszawa 2007, s. 117.

36 List skierowany do przewodniczącego witebskiego miejskiego komitetu wykonawczego, https://vk.com/doc-53090511_179844575 (3 VI 2016). 
pomnika znaleźli się między innymi przedstawiciele nauki. Oni także podkreślali wkład księcia w rozwój białoruskich ziem. Według Anatolija Dułowa, z Witebskiego Państwowego Uniwersytetu im. P. M. Maszerowa, to dzięki rozwojowi terytorialnemu Wielkiego Księstwa Litewskiego za czasów panowania księcia Olgierda, ziemie białoruskie znalazły się w centrum ówczesnego państwa. Sytuacja ta miała sprzyjać rozwojowi kultury, gospodarki, a także wzmacniać status języka starobiałoruskiego jako oficjalnego państwa oraz pomagać w rozszerzaniu wpływów prawosławnej cerkwi w Wielkim Księstwie Litewskim. Oprócz tego badacz zwraca uwagę na to, iż dzięki księciu Olgierdowi reaktywowano osobną i autonomiczną metropolię prawosławną ${ }^{37}$, co miało służyć uniezależnieniu się od wpływów zewnętrznych. Ważnym argumentem dla Dułowa jest również to, że książę Olgierd posiada związki z samym Witebskiem poprzez małżeństwo z księżniczką Marią, a także wkład w rozwój fortyfikacji obronnych miasta w postaci murów i kamiennej fortecy, która była jedną z pierwszych na terytorium WKL. Oprócz tego przyczynił się on do budowy lub remontu witebskich cerkwi Zwiastowania oraz monasteru Św. Ducha ${ }^{38}$.

Mimo tych argumentów pomysł ustanowienia pomnika wywołał spore oburzenie w kręgach reprezentujących mniejszość rosyjską. Najbardziej aktywną grupą, która podjęła działania mające na celu zablokowanie upamiętnienia księcia Olgierda, była organizacja „Russkij Dom” z Witebska. Według statutu działa ona na rzecz rozwoju rosyjskiej kultury i języka, a także utrzymywaniu przyjaznych stosunków między Rosjanami i Białorusinami ${ }^{39}$. W okresie, kiedy rozpatrywano kwestie dotyczące pomnika, przewodniczącym organizacji był Andriej Gereszczanka. Jest to postać znana ze swoich antybiałoruskich wypowiedzi, w których pojawiały się tezy kwestionujące istnienie odrębnego narodu i języka białoruskiego. Członkowie powyższej organizacji wyrażali opinie, że pomnik księcia Olgierda mógłby powstać jedynie w połączeniu z jednoczesnym upamiętnieniem Aleksandra Newskiego oraz legendarnej założycielki Witebska księżnej Olgi. Na takie rozwiązanie jednak władze miasta nie wyrażały zgody. Przeciwnicy pomnika zwracali uwagę na to, iż mógłby on w znacznym stopniu pogorszyć stosunki białorusko-rosyjskie w związku z negatywnym odbiorem księcia Olgierda w Rosji. Taka ocena władcy wynika z licznych wy-

37 Po raz pierwszy osobna metropolia prawosławna została założona przez księcia Witenesa w 1299 r.; szerzej na ten temat pisze A. Mironowicz, Kościół prawostawny w państwie Piastów i Jagiellonów, Białystok 2003.

38 Szerzej o księciu Olgierdzie w wypowiedzi Dułowa, http://vitvesti.by/kultura/olgerd-i-vitebsk-tochki-nad-i.html (18 VII 2016).

39 Statut organizacji Russkij Dom, http://vitrusdom.narod.ru/ustav.rar (7 VI 2016). 
praw wojennych jakie przeprowadził na Moskwę, a także z jego rzekomego negatywnego stosunku do wyznawców prawosławia. Przeciwnicy jako jeden z argumentów przytaczali historię dotyczącą śmierci prawosławnych duchownych, którzy zostali następnie uznani za świętych męczenników. Mieli oni zginąć właśnie z inicjatywy samego księcia Olgierda ${ }^{40}$. W związku z tym jego pomnik, według przeciwników, stanowiłby cios w prawosławie i niebezpieczeństwo dla wspólnej przestrzeni kulturowo-historycznej Państwa Związkowego Białorusi i Rosji, a oprócz tego przyczyniłby się do pogorszenia obrazu Białorusi. Samo miejsce usytuowania pomnika obok cerkwi Zmartwychwstania Pańskiego, w rozumieniu jego przeciwników, było prowokacją i niegodziwością.

Kwestia upamiętnienia księcia Olgierda sięgnęła szczebla centralnego, kiedy jego przeciwnicy dwukrotnie zwrócili się $\mathrm{w}$ formie listów bezpośrednio do prezydenta Białorusi Aleksandra Łukaszenki. W pierwszym z nich, który ukazał się w maju 2013 r., pisano, iż: „Książę Olgierd był agresorem i heretykiem, a także okupantem bez przerwy walczącym ze wszystkimi sąsiadami, niszcząc miasta i mordując pokojowych obywateli. Został zapamiętany w rosyjskiej historii jako okrutny łotr. Straszny ślad zostawił w historii chrześcijaństwa. Cerkiew prawosławna czci pamięć (27 kwietnia) świętych męczenników litewskich, którzy zginęli męczeńską śmiercią z jego rozkazu"41. List został podpisany przez przedstawicieli nauki, a także weteranów II wojny światowej. Kolejny ukazał się już kilka miesięcy później. W czerwcu 2013 r. do prezydenta Białorusi zwrócili się przedstawiciele białoruskiego kozactwa, grup rekonstrukcyjnych, a także komuniści. Również kategorycznie sprzeciwiali się ustanowieniu pomnika księcia Olgierda. Określali go mianem „Litwina-poganina”, który nie należy do białoruskiego narodu. Oprócz tego uważali, iż: «У нашего белорусского народа достаточно своих героев и выдающихся мичностей, миролюбивых созидателей-тружеников и, конечно, героев-воинов, но воинов - защитников родной земли. ОльгерА же - агрессор, а не защитник. Он не был созидателем. Смыслом и главным делом его жизни была война. Он воевал практически беспрерывно со всеми сосеАями, не брезгуя коварством, преАавая союзников. ОльгерА убивац мирных жителей, жёг города и сёма, истязал пленных,

40 Sprawa ta została odnotowana również w wydawanym w Polsce Przeglądzie Prawosławnym, por. A. Radziukiewicz, Wojny polsko-ruskie, http://www.przegladprawoslawny.pl/articles. php?id_n=3210\&id=2 (12 VI 2016), gdzie m.in. zacytowano krytyczną wobec Olgierda wypowiedź witebskiego historyka Wiktora Atapina.

41 List przeciwników ustanowienia skierowany do prezydenta Białorusi Aleksandra Łukaszenki w maju 2013 r., https://regnum.ru/news/polit/1657935.html (7 VI 2016). 
грабил церкви. Мы глубоко убежАены, что такие «подвиги» и такая «слава» не отвечает духу и менталитету нашего народа» ${ }^{42}$. Jednym ze wspólnych elementów tych dwóch listów było ponowne odniesienie się do stosunków białorusko-rosyjskich. Ustanowienie pomnika księcia Olgierda miało zdecydowanie wpłynąć na pogorszenie się dwustronnych relacji, a także, w pewnym stopniu, stanowić symbol zmian zachodzących w polityce historycznej Białorusi. Rosyjskie media w tym okresie często zwracały uwagę na to, iż białoruskie władze zmieniają stosunek do swej historii, odnosząc się bardziej przychylnie do tradycji dotyczącej Wielkiego Księstwa Litewskiego. Na ulicach miast zaczęły pojawiać się plakaty prezentujące postacie związane z WKL, a w Mińsku w 2015 r. odbyła się pierwsza w historii, współorganizowana przez Narodową Akademię Nauk Białorusi, międzynarodowa konferencja naukowa poświęcona w całości Wielkiemu Księstwu Litewskiemu. Ponadto Białorusini zaczęli dyskutować o konieczności ustanowienia innych pomników przedstawiających władców z dziejów WKL, w tym między innymi księcia Mendoga w Nowogródku.

Kwestie związane $\mathrm{z}$ witebskim pomnikiem księcia Olgierda zostały zauważone również w innych krajach. Ze szczególnym zainteresowaniem omawiano ten aspekt na Litwie i w Polsce. Litewskie media opisując wydarzenie koncentrowały się między innymi na krytyce samej formy pomnika cytując przy tym słowa witebskiego historyka Makara Babenko. Jego zarzuty dotyczyły w szczególności uzbrojenia władcy, w tym: braku elementów ochronnych na głowie, połączenia pancerza z kolczugą czy zapożyczeń ze źródeł bizantyjskich, które nie powinny w tym przypadku wystąpić $^{43}$. Oprócz tego zaskakujące dla nich było to, iż Białoruś mianuje się spadkobiercą Wielkiego Księstwa Litewskiego ${ }^{44}$. W przekazach medialnych można było wówczas zauważyć ogólną krytykę tych działań, które według Litwinów spowodowane były pogorszeniem relacji rosyjsko-białoruskich i sytuacją na Ukrainie ${ }^{45}$. W Polsce również odnotowano spór wokół witebskiego pomnika Olgierda. W „Gazecie Wybor-

42 List przeciwników pomnika skierowany do prezydenta Białorusi Aleksandra Łukaszenki w czerwcu 2013 r., http://regnum.ru/news/polit/1668604.html (7 VI 2016)

43 M. Augulyte, LDK kunigaikščio Algirdo paminklas suerzino Vitebsko rusus, http://kultura.lrytas.lt/istorija/ldk-kunigaikscio-algirdo-paminklas-suerzino-vitebsko-rusus.htm (10 VI 2016)..

44 J. Noreikiene, Baltarusijoje dygsta Lietuvos kunigaikščiu paminklai, http://kultura.lrytas.lt/ istorija/baltarusijoje-dygsta-lietuvos-kunigaiksciu-paminklai.htm (10 VI 2016).

45 C. Iskauskas., Kodèl kaimynai savinasi mūsų istorija ir kunigaikščius?, http://www.delfi. lt/news/ringas/abroad/c-iskauskas-kodel-kaimynai-savinasi-musu-istorija-ir-kunigaikscius.d?id=65209057 (10 VI 2016). 
czej” szczególnie akcentowano kwestię znaczenia tej sprawy dla budowy białoruskiej niezależności i wskazywano, że upamiętnienia tego księcia, ściśle wiązało się z polityką i stanem stosunków białorusko-rosyjskich. Autor tego tekstu Andrzej Poczobut podkreślał fakt, iż sama idea zrodziła się w czasie, gdy w Rosji pojawiła się wyraźna fala krytyki wobec prezydenta Białorusi Aleksandra Eukaszenki ${ }^{46}$. W korespondencji Andrzeja Pisalnika z Grodna w „Rzeczpospolitej” ${ }^{47}$, białoruski historyk Igor Mielnikau stwierdził, że „za inicjatywą przeciwników pomnika Olgierda stoi, wspierane przez wpływowe rosyjskie ośrodki o zabarwieniu imperialnym, środowisko zwolenników reaktywacji idei zachodniorusizmu, odmawiającej narodowi białoruskiemu podmiotowości w oderwaniu od podmiotowości rosyjskiej" ${ }^{38}$. Zwolennicy tej idei postrzegali historię Białorusi tylko przez pryzmat historii Rosji. Okres Wielkiego Księstwa Litewskiego i Rzeczypospolitej Obojga Narodów był dla wyznawców zachodniorusizmu okresem obcej okupacji pradawnych ziem rosyjskich ${ }^{49}$.

Protesty przeciwników pomnika nie uzyskały aprobaty ze strony najwyższych władz Białorusi. Na cokole, który stanął w docelowym miejscu już w 2011 r., pojawił się pomnik konny przedstawiający wielkiego księcia litewskiego Olgierda. Jego uroczyste odsłonięcie odbyło się w rocznicę 1040-lecia miasta Witebska, 24 VI 2014 r. Autorem został znany białoruski rzeźbiarz Siergiej Bondarenko ${ }^{50}$. Pomnik o wysokości $3 \mathrm{~m} 60 \mathrm{~cm}$, wykonany z brązu, przedstawia siedzącego na koniu księcia z wyciągniętą przed siebie ręką, na której znajduje się sokół symbolizujący władzę. Wśród mieszkańców Witebska krąży legenda, jakoby jego dłoń skierowana była w stronę Moskwy pokazując drogę pochodu w jej kierunku.

Jednak władze miasta pochylając się nad apelami tej części społeczeństwa, która krytykowała idee pomnika księcia Olgierda i wyrażała aprobatę dla upamiętnienia księcia Aleksandra Newskiego, zdecydowały się na ustanowienie monumentu tego

46 A. Poczobut, Białorusko-rosyjska wojna na pomniki, http://wyborcza.pl/1,76842, 16253143,Bialorusko_rosyjska_wojna_na_pomniki.html?disableRedirects=true (10 VI 2016).

47 A. Pisalnik, Spór o pomniki i sojusz, „Rzeczpospolita”, 14 V 2013.

48 http://www.rp.pl/artykul/1008962-Bialorus--spor-o-pomnik-i-sojusz.html; sprawę tę przedstawił też dość obszernie portal kresy24, https://kresy24.pl/kontrowersyjny-ksiaze-olgierd/(17 VI 2016).

49 https://kresy24.pl/kontrowersyjny-ksiaze-olgierd/(17 VI 2016).

$50 \mathrm{~W}$ pierwszym konkursie na projekt pomnika zwyciężył witebski artysta Valerij Maguchij, lecz później zmieniono wykonawcę; szerzej na ten temat: Т. Матвеева, B Витебске откроют памлтник князю Ольгерду. Но скульптор поменялся, http://news.tut.by/society/402187.html (18 VII 2016). 
władcy. Na placu Tysiąclecia w lipcu 2016 r. przedstawiono wizerunek księcia wraz z żoną księżniczką witebską Aleksandrą ${ }^{51} \mathrm{i}$ ich synem księciem nowogródzkim Wasilijem. Prawdopodobnie jego odsłonięcie wiąże się z próbą zachowania równowagi pomiędzy zwolennikami budowania tożsamości i narodowego etosu na podstawie spuścizny Wielkiego Księstwa Litewskiego a stronnikami koncepcji prorosyjskiej opierającej się na idei tzw. „русского мира”. Zdaniem białoruskiego historyka i archeologa Aleksandra Kraucewicza przykład sporu o pomniki w Witebsku pokazuje toczącą się na Białorusi walkę dwóch kierunków: patriotycznego i narodowego z prorosyjskim ${ }^{52}$. Kwestia ta została zauważona również w Polsce, gdzie przytaczano opinie zarówno przeciwników jak i zwolenników. Wśród nich dominowały te, iż Aleksander Newski nie ma nic wspólnego z Witebskiem, a mające miejsce wydarzenia można określić mianem „wojny pomników”33. Sama jego forma została w Rosji skrytykowana przytaczając opinię przewodniczącego witebskiej organizacji Русский кумьтурный центр „Русь” - Igora Potapowa. Według niego władze miasta określając jego wygląd kierowały się swoimi specyficznymi preferencjami oraz nie zachowały w nim idei jedności, siły i ochrony „русской земли”, a także pozbawiły go „русского Ayxa”. Oprócz tego skrytykował on również użycie języka białoruskiego w napisach pod pomnikiem. Zdaniem Potapowa bardziej adekwatne byłoby zastosowanie języka rosyjskiego ${ }^{54}$.

Zdecydowanie mniej emocji wzbudził pomysł upamiętnienia innego wielkiego księcia litewskiego, księcia Witolda, który stał na czele księstwa w latach 1401-1430.

51 Córka kniazia witebskiego i połockiego Briaczysława Wasilkowicza; określana również jako Paraskiewa; szerzej na ten temat w: А. Аитвина, Ф. Успенский, Заметки о дополнительных христианских именах и почитании святых в культуре средевековой Руси, w: А.М. МолАован (реА.), Вереница литер. К 60-летию В. М. Живова, Moskwa 2006, с. 273-291.

52 «оследнее Аесятилетие в Беларуси идет конкуренция и борьба в чиновничьих кругах. Борются Ава течения - национальное, патриотическое, благодаря которому в том же Витебске поставили памятник ОльгерАу, а второе - российское. Памятник Александру Невскому - это ответ пророссийской части элиты. И я полагаю, что этот ответ быи сАелан поА прямым давлением из Москвы. В России отслеживают все, что Аелается в Беларуси, очень болезненно реагируют на каждую вывеску и объявление на белорусском языке. Поэтому установление этого памятника - это проявление наступления «русского мира»», Алексанар Кравцевич, https://charter97.org/ru/news/2016/6/20/209853/ (16 VII 2016).

53 A. Poczobut, Białoruska wojna na pomniki, http://wyborcza.pl/1,75399,20287359, bialoruska-wojna-na-pomniki.html?disableRedirects=true (16 VII 2016).

54 «На памятнике Александру Невскому в Витебске нет русского духа», https://regnum. $\mathrm{ru} /$ news/society/2149470.html (16 VII 2016). 
Jednak tym razem inicjatywa miała charakter międzynarodowy. Duży wkład w ustanowienie pomnika miała litewska organizacja „Za społeczeństwo obywatelskie”, która współpracowała w tej kwestii z mniejszością litewską na Białorusi i władzami białoruskimi. Pomnik oficjalnie odsłonięto we wrześniu 2010 r. we wsi Pielasa (obwód grodzieński) ${ }^{55}$. W uroczystościach udział wzięli ambasador Litwy Edminas Bagdonas, przedstawiciele litewskiego parlamentu i ministerstw, a także stowarzyszenia zrzeszające Litwinów na Białorusi oraz władze lokalne rejonu werenowskiego. Ponad sześciometrowy pomnik autorstwa litewskiego artysty Aglimantasa Sakalauskasa wykonany został w drewnie dębowym, przedstawia księcia z koroną na głowie, trzymającego w lewej dłoni berło, a w prawej miecz ${ }^{56}$. Inskrypcje wykonano zarówno w języku białoruskim jak i litewskim.

Jednak nie wszystkie pomysły związane z upamiętnieniem władców Wielkiego Księstwa Litewskiego udało się dotychczas zrealizować. W 2009 r. w Nowogródku (obwód grodzieński) miał stanąć pomnik wielkiego księcia litewskiego (1236-1263), króla Litwy (1253-1263) Mendoga ${ }^{57}$. To właśnie w tym mieście w 1253 r. odbyła się koronacja władcy. Aczkolwiek formalności związane z ustanowieniem pomnika opóźniały się i konkurs na jego realizację ogłoszono dopiero pod koniec $2011 r^{58}$. Spośród projektów zdecydowano się wybrać dwa: Sergeya Bondarenko i Pavla Luka. Mimo tego, władze centralne zdecydowały się zrezygnować z finansowania przedsięwzięcia ${ }^{59}$. Wówczas przedstawiciele lokalnej administracji postanowili o rozpoczęciu zbiórki pieniężnej w celu pokrycia kosztów. Rezygnacja władz spowodowała, że do dzisiaj (początek 2018 r.) nie udało się zebrać sumy potrzebnej na realizację pomnika ${ }^{60}$. Jednak, podobnie jak w przypadku pomnika księcia Witol-

55 Na Białorusi znajduje się również inny pomnik przedstawiający wielkiego księcia litewskiego Witolda. Powstał on na początku lat dziewięćdziesiątych w Grodnie dzięki wsparciu Litewskiego Funduszu Kultury. Wyrzeźbiony w litym drewnie dębowym został usytuowany nieopodal mostu prowadzącego do Starego Zamku w Grodnie.

56 М. Горевой, В Вороновском районе открыт памлтник великому князю ВКА Витовту, https://news.tut.by/culture/198204.html (2 VII 2017).

57 Jak dotychczas jedyny pomnik Mendoga znajduje się w Wilnie przy Litewskim Muzeum Narodowym. Został odsłonięty z okazji 750-lecia koronacji Mendoga na króla Litwy 6 VII 2003 r. 58 А. Коровайко, М. Шкиленок, Памедор Я Реуцкий., Многострадальный памятник Миндовгу все же появится в Новогрудке?, https://news.tut.by/tv/264483.html (2 VII 2017).

59 Белорусам не нужен памлтник Миндовгу, http: / /www.belaruspartisan.org/life/223395/ (2 VII 2017).

60 Według prasy białoruskiej, która powoływała się na szacunki naczelnika oddziału kultury władz lokalnych w Nowogródku Aleksandra Karaczana, koszt ustanowienia pomnika wyniósłby 
da, upamiętnienie Mendoga nie wywoływało tak skrajnych emocji jak w stosunku do pomnika Olgierda w Witebsku.

Innym ciekawym przedsięwzięciem związanym z polityką historyczną Białorusi było zorganizowanie w 2012 r. głosowania (o charakterze rekomendacyjnym) za pośrednictwem portalu internetowego władz lokalnych w Mińsku, dotyczącego upamiętnienia ważnych postaci i wydarzeń dla historii kraju ${ }^{61}$. Nie zabrakło wśród nich osób zasłużonych dla Wielkiego Księstwa Litewskiego czy Rzeczpospolitej. Istotnym, z punktu widzenia spuścizny WKL i zachodniego kręgu kulturowego, był pomnik 1000-lecia białoruskiej państwowości ${ }^{62}$. Cieszył się on również największym poparciem Białorusinów ${ }^{63}$. Jednak wśród rosyjskich publicystów wywoływał skrajnie negatywne emocje. Odnosili się oni krytycznie do samej nazwy pomnika, która sugerowała 1000-letnie istnienie Białorusi ${ }^{64}$. Swój sprzeciw wyrażali również poprzez negowanie zasług postaci mających zostać upamiętnionych $w$ ramach pomnika, między innymi, Wincentego Konstantego Kalinowskiego nazywano „polskim terrorystą" ${ }^{65}$. Działania białoruskich władz związane z powrotem do spuścizny Wielkiego

około 40 tys. rubli białoruskich. Do końca 2011 r. udało się zebrać kwotę 1200 rubli białoruskich, por. http://www.kp.by/daily/24475/633191/ (2 VII 2017), http://www.belaruspartisan.org/ life/223395/ (2 VII 2017).

${ }^{61} \mathrm{~W}$ plebiscycie można było oddać głos na następujące inicjatywy: 1. Miejsce pamięci/tablica pamięci ku czci ofiar ataku terrorystycznego w mińskim metrze z 11 IV 2011 r. 2. Miejsce pamięci/tablica pamięci ku czci rannych i ofiar ataków terrorystycznych z 14 i 22 września w Witebsku, 3 VI 2008 r. i 11 IV 2011 r. w Mińsku. 3. Pomnik Aleksego II (patriarcha Moskwy). 4. Rzeźba przedstawiająca herb Mińska. 5. Miejsce pamięci/tablica pamięci „Zjednoczenie ziem Białorusi”. 5. Pomnik/kompozycja „1000-lecie białoruskiej państwowości (osobistości w historii Białorusi)". 6. Pomnik Gleba Vseslavivha. 7. Pomnik Piotra Maszeraua., por. http://minsk.gov.by/ru/ freepage/other/20111018/ (2 VII 2017).

62 Pomnik miał być kompozycją upamiętniającą m.in.: Lwa Sapiehę, Konstantego Ostrogskiego, Szymona Budnego, Tadeusza Kościuszkę, Adama Mickiewicza, Napoleona Ordę, Jana Barszczewskiego, Janka Kupałę i innych.

63 И..Снежана, Кто достоин памлтника в Минске?, https://news.tut.by/society/268983. html (2 VII 2017).

64 Rosyjska agencja Regnum za pośrednictwem swojego portalu informowała, iż samodzielne białoruskie państwo sformowało się dopiero w XX w., od 1 I 1919 r., czyli utworzenia radzieckiej Białorusi, por. B Минске планируется поставить памятник «тысячелетию белорусской государственности", https://regnum.ru/news/polit/1459054.html (2 VII 2017).

65 Власти Белоруссии увековечат польского террориста в памятнике «1000-летию белорусской государственности», https://regnum.ru/news/polit/1708160.html (2 VII 2017). 
Księstwa Litewskiego określano mianem „białorutenizacji” ${ }^{6}$. Jednak władze lokalne oraz centralne nie zdecydowały się dotychczas (lipiec 2017 r.) na realizację projektu, którzy uzyskał największe poparcie spośród wszystkich propozycji.

Ufundowanie pomnika księcia Olgierda w Witebsku, a także inne wydarzenia związane $\mathrm{z}$ upamiętnianiem postaci i symboli związanych $\mathrm{z}$ okresem funkcjonowania Wielkiego Księstwa Litewskiego pokazują zachodzące zmiany w postrzeganiu i kształtowaniu polityki historycznej przez białoruskie władze. Coraz częściej odnoszą się one do tych zdarzeń i dziejów, które wcześniej wydawały się być pomijane lub przemilczane. Być może wiąże się to z procesem próby otwarcia się Białorusi na Zachód. Jak pokazała kwestia dotycząca pomnika księcia Olgierda w Witebsku, białoruska polityka historyczna cały czas wzbudza skrajne opinie wśród społeczeństwa. Wydarzenia te nie są prawdopodobnie zwiastunem wielkiego przełomu w stylu i metodach uprawiania polityki historycznej. Nie należy oczekiwać zupełnego odwrotu od dotychczasowej retoryki, każdy taki kolejny symbol stanowi potwierdzenie występujących wśród społeczeństwa białoruskiego dążeń do zbliżania się do kręgu kultury zachodnioeuropejskiej i dowodzi trwających na Białorusi procesów budowy własnej narodowej tożsamości i identyfikacji. Rosja, mająca w tym zakresie pewne wsparcie w działających na Białorusi środowiskach optujących za ścisłymi związkami białorusko-rosyjskimi, zapewne nadal będzie głównym krytykiem tych zmian. Wszelkie działania białoruskich władz zmierzające do zwiększenia rangi języka białoruskiego i odnoszenia się do spuścizny Wielkiego Księstwa Litewskiego spotkają się z oskarżeniami o zagrożenie dla języka rosyjskiego i postępującą białorutenizację społeczeństwa. Władze Białorusi rezygnując z niektórych przedsięwzięć w sferze polityki historycznej, związanych bezpośrednio z WKL albo Rzeczpospolitą, starają się doprowadzić do złagodzenia opinii Rosji i zaspokojenia interesów prorosyjskich grup w kraju.

66 Белорусский писатель: Нельзя подменить историю белорусского народа историей польско-^итовской шияхты, https://regnum.ru/news/polit/1485394.html (2.07.2017). 
Nadesłany: 2 XII 2017

Nadesłany po poprawkach recenzyjnych: 15 III 2018

Zaakceptowany: 16 III 2018

prof. UAM dr hab. Marek Figura

Instytut Wschodni

Wydział Historyczny

Uniwersytet im. Adama Mickiewicza w Poznaniu

ul. Umultowska 89d

61-809 Poznań

marek.figura@gmail.com

mgr Łukasz Staśkiewicz

Instytut Wschodni

Wydział Historyczny

Uniwersytet im. Adama Mickiewicza w Poznaniu

ul. Umultowska 89d

61-809 Poznań

lukaszstaskiewicz@wp.pl

\section{Commemoration of the rulers of the Grand Duchy of Lithuania in the historically-oriented policy of contemporary Belarus}

Historically-oriented policy is a fairly important element of preserving national identity and building historical awareness. It is reflected, among other things, in the attitude towards monuments. In the past few years, Belarus has witnessed changes in the central authorities' and the society's respective perceptions. More and more frequently, discussions are held about the legacy of the Grand Duchy of Lithuania and its role in forging Belarus' statehood. Among the elements of the historically-oriented policy in Belarus are issues related to monuments to figures from the times of the Grand Duchy of Lithuania. The society's opinions are extreme, both approving of the new developments and fiercely opposing them. The monument to the Lithuanian grand prince Algirdas in Vitebsk has been at the centre of this dispute, arousing the most intensive emotions. In the past years, efforts have been also made to commemorate prince Vytautas, king Mindaugas as well as Konstanty Ostrogski and Lew Sapieha. 


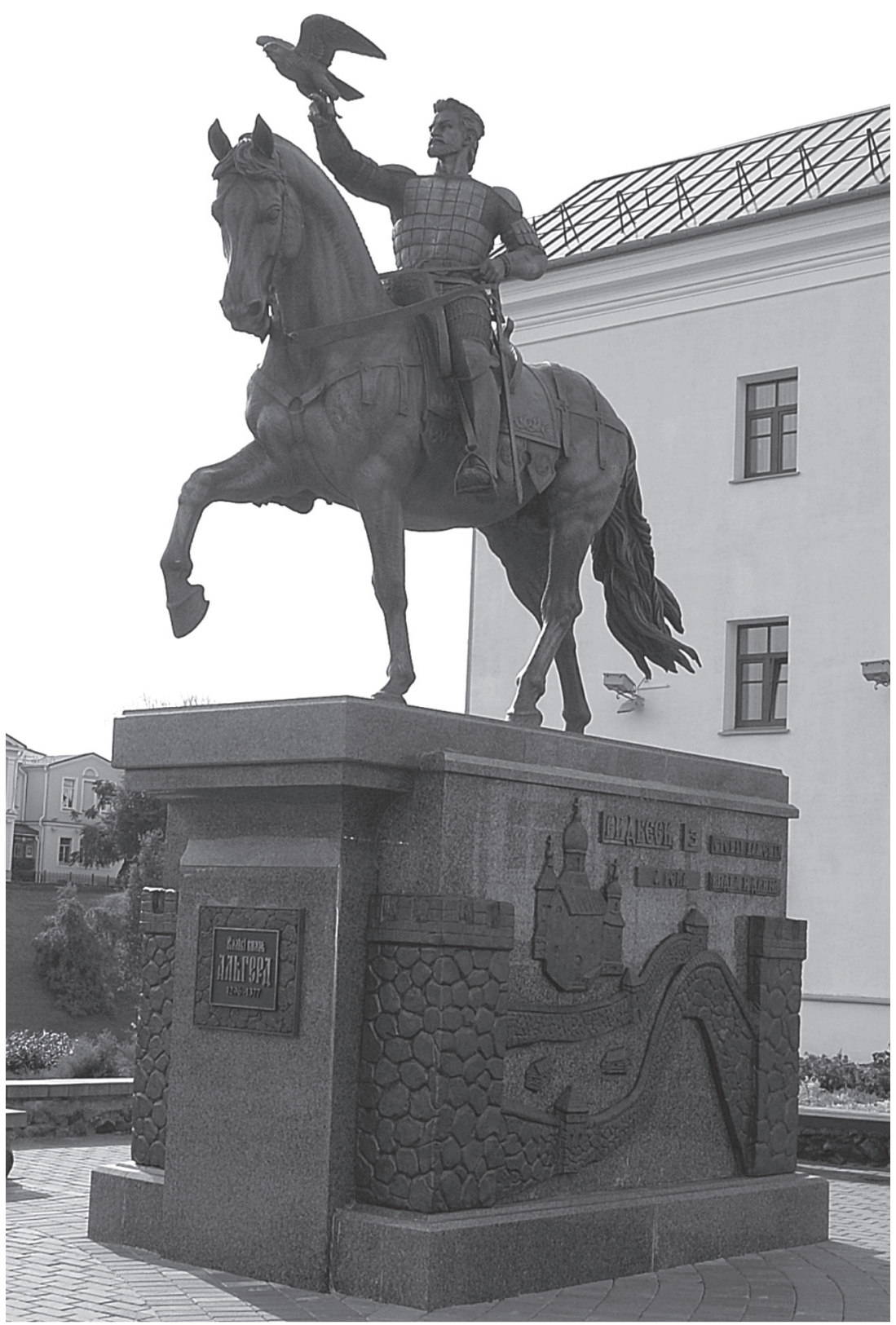

Fot. 1. Pomnik księcia Olgierda w Witebsku. Autor: Łukasz Staśkiewicz. 